\title{
Seasonal evolution of runoff generation on agricultural land in the Belgian loess belt and implications for muddy flood triggering
}

\author{
Olivier Evrard ${ }^{\mathrm{a}, \mathrm{d}, *}$, Karel Vandaele ${ }^{\mathrm{b}}$ Charles Bielders ${ }^{\mathrm{c}}$ \\ Bas van Wesemael ${ }^{\text {a }}$ \\ ${ }^{a}$ Département de Géographie, Université catholique de Louvain, Place L. Pasteur 3, \\ B-1348 Louvain-la-Neuve, Belgium \\ ${ }^{\mathrm{b}}$ Watering van Sint-Truiden, Minderbroedersstraat 16, B-3800 Sint-Truiden, \\ Belgium \\ ${ }^{\mathrm{c}}$ Département des Sciences du Milieu et de l'Aménagement du Territoire, \\ Université catholique de Louvain, Croix du Sud 2 Bte 2, B-1348 Louvain-la-Neuve, \\ Belgium \\ ${ }^{\mathrm{d}}$ Fonds pour la formation à la Recherche dans l'Industrie et l'Agriculture \\ (F.R.I.A.), Belgium
}

\begin{abstract}
Muddy floods due to agricultural runoff are a widespread and frequent phenomenon in the European loess belt, and particularly in central Belgium. These floods are triggered when high quantities of runoff are generated on cropland and cause severe erosion. Three soil surface characteristics are relevant to determine the runoff potential of cultivated soils: soil cover by crops and residues, soil surface crusting and roughness. These characteristics have been observed on 65 cultivated fields throughout 2005. A heavy rainfall event representative for events triggering muddy floods in the region $\left(60 \mathrm{~mm} \cdot \mathrm{h}^{-1}\right.$ during 30 minutes) has been simulated using a $0.5 \mathrm{~m}^{2}$ simulator on fields with the 17 most observed combinations of soil surface characteristics in central Belgium. In the case of (ploughed) bare uncrusted soils, runoff is not observed, nor in the case of soils covered by crops, showing a transitional crust and a moderate roughness $(1-2 \mathrm{~cm})$. In the cases where runoff has been observed, mean runoff coefficients ranged from 13\% (wheat in July) to $58 \%$ (sugar beet or maize in May and June). Grassed buffer strips (GBS) and grassed waterways (GWW) show a higher runoff coefficient ( $62 \%$ for GBS and $73 \%$ for GWW) than most cultivated soils (13-58\%). Furthermore, it is demonstrated that small plot measurements can be used to estimate runoff generation at the field scale. A classification of runoff generation risk based on the surveys of soil surface characteristics has been applied to common crops of central Belgium. February as well as the period between May and September are the most critical for runoff at the field scale. However, it appears from monitoring of a 16ha-catchment that the highest
\end{abstract}


runoff volumes and peak discharges are recorded between May and August after heavy rainfall, explaining why $85 \%$ of muddy floods are recorded during this period in central Belgium.

Key words:

runoff coefficient, steady infiltration rate, muddy floods, grassed areas, scale effect

\section{Introduction}

2 A muddy flood is defined as water flowing from agricultural fields carrying large quantities of soil as suspended sediments or bedload (Boardman et al., 2006). It is therefore a fluvial process rather than a mass movement one. In central Belgium, numerous villages are frequently affected by such floods (Vandaele and Poesen, 1995; Verstraeten and Poesen, 1999; Bielders et al., 2003; Evrard et al., 2007a). This situation is also reported from other countries in the European loess belt (Boardman et al., 1994), especially in Northern France (Souchère et al., 2003) and in the UK (Boardman et al., 2003). In central Belgium, about $90 \%$ of muddy floods are generated on hillslopes (10-30 ha) and in small catchments (30 - 300 ha; Evrard et al., 2007a). Rommens et al. (2006) calculated the Holocene alluvial sediment storage in a small river catchment $\left(52 \mathrm{~km}^{2}\right)$ of the Belgian loess belt. They found that sediment supply towards the flood plain has occurred at rates of $1.3 \mathrm{t} \cdot \mathrm{ha}^{-1} \cdot \mathrm{yr}^{-1}$ since the Medieval period, resulting in a gradual filling up of the Pleistocene river valleys. Since $50 \%$ of the sediment that was eroded from the hillslopes during the Holocene was stored in colluvial deposits mainly located in dry zero-order valley bottoms, muddy floods are the mostly likely process carrying sediments from the dry valleys and transporting them to the flood plains.

Nowadays, these floods occur when large amounts of runoff are generated on crusted cultivated soils. Mean rainfall depths required to trigger muddy floods are lower in May and June $(25 \pm 12 \mathrm{~mm})$ than between July and September (46士20 mm; Evrard et al., 2007a). Runoff and erosion are mainly produced in spring and early summer on fields with summer crops at an early development stage (Vandaele and Poesen, 1995). Processes such as slaking of aggregates, raindrop impact, microcracking and physico-chemical dispersion lead to the formation of a soil crust (Bresson and Boiffin, 1990). Several stages of crust development have been characterised. First, a structural crust is formed by local rearrangement of particles. Then, when particles are transported and

* Olivier Evrard. Phone: 0032(0)10472991 Fax : 0032(0)10472877

Email address: evrard@geog.ucl.ac.be (Olivier Evrard). 
deposited further away, a depositional crust can be observed (Valentin and Bresson, 1992). Crust development reduces the infiltration capacity as well as surface roughness. Oriented roughness describes the systematic variations in topography due to farm operations. Random roughness is related to soil clodiness and determines depressional storage (Onstad, 1984). Such soil surface features are important controlling factors for runoff. A typology of soil surface conditions of cultivated soils has been proposed in the context of the French silt loam soils (e.g. Bresson and Boiffin, 1990; Le Bissonnais et al., 2005). According to this method, surface crust development, roughness and vegetation cover are considered the most relevant dynamic characteristics for describing and classifying cultivated soils with respect to their potential for generating runoff and erosion (Le Bissonnais et al., 2005). This typology has been developed in the framework of a runoff/erosion expert-based model (STREAM, Cerdan et al., 2001). This model focuses on the dominant runoff/erosion processes to avoid over-parameterisation and the associated uncertainties. It is used as a decision support tool for the design of control measures against runoff and muddy floods. The main advantage of expert-based models is that they do not need as many input parameters and variables as physically-based models (e.g. LISEM, De Roo et al., 1996) which require for instance parameters for crust hydraulic properties. STREAM only needs steady infiltration rate and sediment concentration data. However, the main drawback of expertbased models is that the decision rules are only valid for the local conditions for which they have been derived. Although input parameters such as runoff coefficients fitted by trial and error yield reasonable results in hydrological models (e.g. Evrard et al., 2007b), this approach can lead to an equifinality problem (i.e. obtaining the right results for the wrong reasons), and should be avoided where possible (Beven, 2001). The measurement of the model input parameters in the field using a consistent methodology should decrease the risk of equifinality.

Several techniques exist to determine the field-saturated infiltration rate. Constant head infiltrometers have extensively been used, but the estimates are unreliable for stratified soils or when the crust is disturbed to install the infiltrometer (Léonard et al., 2006). In other studies, rainfall simulations have been carried out in the laboratory (Pan and Shangguan, 2006), or experimental plots exposed to natural rainfall have been monitored for runoff during several years (Léonard et al., 2006). However, to cover the whole range of soil surface conditions related to different types of land cover, numerous plots are needed. Furthermore, the occurrence of runoff remains highly uncertain over a period of a few years only. Consequently, rainfall simulations performed on selected surfaces representing the range of surface conditions observed throughout the year are more efficient. The problem is that rainfall simulations are carried out on small plots (generally up to $1 \mathrm{~m}^{2}$ ) while required input (e.g. for STREAM) must characterise an entire field (typically 1 to 6 ha). Since a scale effect is likely to occur, the reliability of using micro-plot measurements to characterise 
1 a field must be investigated. For instance, Cerdan et al. (2004) calculated a significant decrease in runoff coefficient when the study area increased from $3500 \mathrm{~m}^{2}$-plots to catchments (90-1100 ha).

4 The objective of this paper is to characterise runoff generation on agricultural 5 land in the Belgian loess belt, based on surveys of soil surface characteristics, 6 rainfall simulations on microplots and field monitoring. More precisely, this 7 paper aims: (i) to document the temporal variation of soil surface properties 8 of agricultural fields in the Belgian loess belt by identifying the dominant com9 binations of characteristics observed throughout the year,(ii) to relate these - combinations of soil surface characteristics to a final runoff coefficient and (iii) 1 to develop a simple index to assess runoff generation risk at field and catchment scales. The implications of these findings for muddy flood triggering at 3 the catchment scale will be discussed.

\section{Materials and methods}

\subsection{Study area}

The Belgian loess belt (c. $9,000 \mathrm{~km}^{2}$ ) is a plateau with a mean altitude of $115 \mathrm{~m}$ and a topography gently sloping to the North (Fig. 1a). It is dissected by valleys having generally a North-South orientation. Most soils are loess-derived haplic luvisols (World Reference Base, 1998). Mean annual temperature ranges from 9 to $10{ }^{\circ} \mathrm{C}$, while mean annual precipitation in central Belgium varies between 700 and $900 \mathrm{~mm}$ (Hufty, 2001). Rainfall is evenly distributed throughout the year, but erosivity shows a peak between May and September (Verstraeten et al., 2006). Arable land covers on average $65 \%$ of the total surface (Statistics Belgium, 2006). Main crops are winter wheat, industrial and fodder crops (sugar beets, maize, oilseed rape and flax), as well as potatoes. Orchards are restricted to the northeastern part of the loess belt, around the town of Sint-Truiden (covering up to $65 \%$ of the total area in this region, vs. less than $5 \%$ elsewhere in the loess belt). 
2 The monitoring of soil surface characteristics and the rainfall simulations have 3 been carried out in an experimental field ( 6 ha; Fig. 1 b), a hillslope (16 ha; 4 Fig. 1c) and a catchment (300 ha; Fig. 1d) of the Belgian loess belt. These 5 sites consist entirely of cropland, except for the largest one, which is also 6 covered by c. $10 \%$ of orchards (Fig. 1d). They are characterised by common 7 crop rotations alternating winter cereals and summer crops. In addition, sev8 eral grass buffer strips (GBS) and a grassed waterway (GWW) have been 9 installed in the 300 ha-catchment (Fig. 1d). Grass species consist of a mix of - Lolium multiflorum Lam., Lolium perenne L., Festuca rubra L. subsp. rubra and Dactylis glomerata L. Haplic luvisols and haplic regosols are present in the three sites. A topsoil sample of haplic luvisols contains on average $18 \%$ sand $(\mathrm{SD}=14 \%), 60 \%$ silt $(\mathrm{SD}=31 \%)$ and $22 \%$ clay $(\mathrm{SD}=18 \%)$, as documented in the Aardewerk database restricted to the Belgian loess belt (Van Orshoven 5 et al., 1988). Surface layers of haplic regosols contain on average $20 \%$ sand 6 $(\mathrm{SD}=16 \%), 56 \%$ silt $(\mathrm{SD}=32 \%)$ and $24 \%$ clay $(\mathrm{SD}=18 \%)$. Mean soil organic 7 matter content reaches c. $2 \%$ (Goidts and van Wesemael, in press). All study \& sites are equipped with tipping-bucket raingauges. Calibrated sharp-crested 9 weirs and automatic water level gauges (Easylog 3000, Microware Software, - Villanova d'Asti, Italy) are installed downstream of the 6-ha experimental field 1 and the 16-ha hillslope. A crest stage recorder has been installed at the outlet 22 of Sint-Truiden catchment to measure water level when runoff occurred. Such 23 a recorder consists of a plastic tube with a length of water-sensitive tape which 24 changes colour on contact with water (Table 1).

\subsection{Soil surface characterisation}

\footnotetext{
According to Le Bissonnais et al. (2005), the most relevant dynamic characteristics for characterising runoff and erosion potential of cultivated fields 28 at a given time are : (i) surface roughness (Table 2a); (ii) the development 29 of soil surface crusts (Table 2b); (iii) the vegetation and plant residue cover - (Table 2c) and (iv) the presence of wheel tracks. These characteristics were 31 determined by visual observation each month throughout 2005 in all 65 fields 32 of the three study sites. Each field is characterised by one combination of 33 surface features. Field observations were then summarised to select the most ${ }_{34}$ frequent combinations on which rainfall simulations should be performed. Se${ }_{5}$ lected plots for rainfall simulation tests always had a slope gradient between 363 and $5 \%$, which is common in the Belgian loess belt. Before the experiment, 37 soil moisture varied between 15 and $20 \%$.
} 
For each selected combination of soil surface characteristics, the rainfall simulations have been performed on three replicates using an Amsterdam-type simulator. A detailed description of this type of simulator is given by BowyerBower and Burt (1989). The dripping plate is $105 \times 55 \mathrm{~cm}$ in size and the runoff area covers $0.5 \mathrm{~m}^{2}$. Below the dripping plate a randomiser is attached. It scatters, breaks up and coalesces water drops into a wider distribution of drop sizes than a spray-type simulator. A gutter is installed downstream of the simulator to collect runoff. Water-based sealants (e.g. acrylate kit, silicone) are used to obtain a good seal and prevent leakage into the soil. Before the simulation, a soil sample is taken to determine its moisture content. Simulated rainfall reaches $60 \mathrm{~mm} \cdot \mathrm{h}^{-1}$ during 30 minutes. Such a rainfall event has a 100-year return period after Delbeke (2001). According to a long-term (1977-2001) database on muddy flood occurrence in a $285 \mathrm{~km}^{2}$ river basin of central Belgium, $85 \%$ of muddy floods occur between May and September. They are triggered by heavy thunderstorms (e.g. $60 \mathrm{~mm}$ in one hour, Evrard et al., 2007a). At an intensity of $60 \mathrm{~mm} \cdot \mathrm{h}^{-1}$, medium drop size equalled 5 $\mathrm{mm}$ and, after a fall height of $1.70 \mathrm{~m}$, kinetic energy reached $13 \mathrm{~J} . \mathrm{m}^{-2} . \mathrm{mm}^{-1}$. Intensity is controlled using a graduated scale on the water reservoir and a chronometer. A wind shield can also be installed if necessary.

Soil infiltration capacity decreases during rainfall, due to the reduction of pressure gradients within the soil and to the degradation of the soil surface structure (Selby, 1993). The steady infiltration rate is one of the parameters required by the STREAM model. It is determined by substracting measured runoff from the applied rainfall after runoff has reached a steady state. Infiltration into loess soils is mainly controlled by soil surface crust development (Römkens et al., 1995), which demonstrates the dominance of hortonian overland flow processes in the region. In the results section, mean values are given \pm one standard deviation.

Tukey-Kramer's Honestly Significant Difference (HSD) test is computed using the SAS Enterprise Guide statistical package (SAS Institute Inc., Cary, NC, USA) to compare the means of runoff coefficient and final infiltration rate obtained for the different rainfall simulations. This test is performed after the ANOVA null hypothesis of equal means has been rejected to determine which means are significantly different. 


\subsection{Comparison of measured runoff coefficients with other methods}

2 The aim of this section is to confront the results of the rainfall simulations 3 with the ones obtained by other studies carried out in similar loess areas of 4 northwestern Europe (Cerdan et al., 2001; Van Oost, 2003). For two different 5 crops (winter wheat and sugar beet), runoff coefficients have been calculated 6 for a 30 minutes rainfall event with an intensity of $60 \mathrm{~mm} \cdot \mathrm{h}^{-1}$. The evolution 7 of soil surface characteristics throughout the year has been taken into account 8 to evaluate runoff coefficients for the two crops. Runoff coefficients at constant 9 infiltration rates derived from the results of the rainfall simulations are compared with (i) the ones obtained using infiltration values proposed by Cerdan et al. (2001) for the context of Normandy and with (ii) the ones calculated according to the SCS Curve Number (CN) technique (USDA-SCS, 1973) modified by Van Oost (2003). The CN technique is used to estimate runoff depth from rainfall depth (Eq.1 and 2).

$$
\begin{gathered}
R_{C N}=\left(P-I_{a}\right)^{2} /\left[\left(P-I_{a}\right)+S\right] \quad \text { for } P>I_{a} \\
R_{C N}=0 \quad \text { for } P<I_{a}
\end{gathered}
$$

Where $R_{C N}$ is the estimated direct surface runoff $(\mathrm{mm}), \mathrm{S}$ is the potential maximum retention $(\mathrm{mm}), I_{a}$ is the initial abstraction $(\mathrm{mm})$ and $\mathrm{P}$ is the total precipitation $(\mathrm{mm})$.

The $\mathrm{CN}$ is related to the retention parameter $\mathrm{S}$ for which the empirical equation $I_{a}=0.2 S$ was adopted (Eq.3).

$$
C N=25400 /(S+254)
$$

The modification developed by Van Oost (2003) aims to take the evolution of crop cover and crusting stage of arable land into account to compute the Curve Number (Eq.4).

$$
C N=C N_{S C S}-\left(C_{c} / 100 \cdot c_{1}\right)+\left(C_{r} / 4 \cdot c_{2}\right)
$$

Where $C N_{S C S}$ is the maximum CN derived from USDA-SCS (1973); $C_{c}$ is the crop cover percentage; $C_{r}$ is the crusting stage (Le Bissonnais et al., 2005) and $c_{1}$ and $c_{2}$ are coefficients (Van Oost, 2003). 


\section{Results and discussion}

\subsection{Identification of dominant soil surface combinations throughout the year}

Among the 60 possible combinations of crust, roughness and soil cover by crop and residues (Table 2), only 38 have been observed in the field and 15 represented more than $2 \%$ of the fields throughout the year (accounting for $85 \%$ of fields in total; Fig. 2). Technical problems have prevented to carry out rainfall simulations during winter. The lack of simulations in winter is acceptable since according to an exhaustive database of muddy floods for the 1977-2002 period in a $285 \mathrm{~km}^{2}$ area of central Belgium, $90 \%$ of floods occur between April and October (Evrard et al., 2007a) and c. $70 \%$ of rainfall erosivity is concentrated between May and September (Verstraeten et al., 2006). The simulated rainfall event is highly unlikely in winter. Consequently, rainfall simulations have been performed between April and October on the fields having one of the 15 most common combinations of soil surface characteristics (Fig. 2).

Only bare soils (C1) and soils with a dense cover (C3) are represented among these 15 selected combinations (Fig. 3). This is due to the the rapid crop growth between monthly surveys. However, to take the crop cover effect fully into account, simulations have also been carried out on two soil surface state combinations with an intermediate soil cover by vegetation (C2). They correspond to growing maize and sugarbeet or cover crops in spring and autumn 
(C2-F11-R2 and C2-F12-R2; Table 3). Moreover, rainfall has also been simulated on maize lines as well as on wheel tracks. In total, simulations have hence been carried out on 19 different soil surface states.

Ploughed and bare fields are common in winter and spring (e.g. C1-F0-R4, C1F0-R3 right after tillage; Fig. 3). Between April and June, soils are prepared for the sowing of maize or row and industrial crops. Ploughing and preparation of a seedbed destroy the crust and increase roughness. This leads to an evolution of the soil surface conditions from C1-F11-R3, C1-F11-R2 and C1-F12-R2 before sowing to C1-F0-R1 and C1-F0-R2 right after sowing. At the end of spring, two main types of fields can be observed : (i) soils with a dense crop cover in the case of winter cereals, flax or oilseed rape (C3-F12-R1, C3-F12R0, C3-F2-R0); and (ii) soils poorly covered by growing crops, mainly sugar beets, maize, potatoes and carrots (C1-F11-R1; C1-F12-R1). In summer, most soils are densely covered by the crops but the crust is disturbed by earthworm activity and dessiccation (e.g. C3-F12-R1 for winter wheat and sugar beet). Finally, in autumn, soils are generally covered by crop residues (C3-F11-R1) or cover crops (C2-F11-R2, C2-F12-R2, C3-F12-R1, C3-F2-R2). A few bare soils have also been observed during this season (C1-F0-R1, C1-F11-R1).

\subsection{Runoff generation on cultivated soils}

Among the 17 selected combinations of soil surface characteristics, only 8 have produced runoff during the rainfall simulations (Table 3). Runoff has also been observed on maize lines as well as on wheel tracks (Table 4). In winter and early spring, bare and rough surfaces with a fragmentary state have not produced runoff (C1-F0-R4, C1-F0-R3, C1-F0-R2, C1-F11-R3). Such ploughed fields are not crusted and infiltration rates are very high. Moreover, no runoff has been observed for surfaces with a dense crop cover that are not completely crusted (C3-F11-R1). On rough and imperfectly crusted fields with growing crops (C2F11-R2) or fully developed crops (C3-F11-R2, C3-F12-R2), no runoff has been observed either.

A high runoff coefficient ( $58 \pm 8 \%)$ has been observed for sugar beets and maize (C1-F12-R1) in May and June. Strongly crusted surfaces with a dense crop cover (C3-F12-R0, C3-F2-R0) are also characterised by runoff coefficients of c. $50 \%$. The runoff coefficient strongly decreases when the soil is less crusted or rougher (13 $\pm 5 \%$ for C3-F12-R1). This is typically the case of winter wheat before the harvest in July and early August. This increase of infiltration is explained by the seasonal activity of burrowing animals as well as the appearance of dessiccation cracks due to shrinkage in the soil surface (Schröder and Auerswald, 2000; Lamandé et al., 2003). This crust cannot be regenerated 
1 by splash erosion during subsequent rainfall because of the dense crop cover intercepting rainfall.

Runoff coefficients on the maize lines where runoff preferentially concentrates are much higher $(90 \pm 3 \%)$ than on the surrounding area. On wheel tracks, runoff coefficients are very high ( $95 \pm 3 \%$ on average) because the soil is fully crusted and compacted.

The runoff coefficients of the cultivated surfaces have been plotted for the different classes of crop cover, surface crusting and roughness (Fig. 4). Runoff increases with crust development. No runoff has been observed for the fragmentary (F0) rough and bare soils. In contrast, the highest runoff coefficients are observed for the strongly crusted soils (F12, F2). Roughness increases the apparent infiltrability by decreasing the runoff contributive area (Léonard et al., 2006). Rougher soils produce less runoff and runoff has never been observed on very rough soils (R3-R4; Fig. 4). A dense vegetation cover leads to a high interception of raindrops, reducing the kinetic energy of the raindrops and hence preventing soil crusting (Morgan, 1995). In addition, the runoff coefficient of soils with scattered depositional crust and a low roughness (C1F12-R1) is reduced by c. $60 \%$ when the crop cover increases (C3-F12-R1), mainly because of dessiccation cracks and the activity of soil fauna creating pores at the soil surface.

\subsection{Runoff generation on grassed areas}

Overall, grassed areas have a higher runoff coefficient $(62 \pm 5 \%$ for GBS and $73 \pm 3 \%$ for GWW) than cultivated soils (between $13 \pm 5$ and $58 \pm 8 \%$ ), except for maize lines $(90 \pm 3 \%)$ and wheel tracks (95 $\pm 3 \%$; Table 4). A possible explanation is that soils where grass has been sown are not ploughed anymore. The soil surface is hence progressively compacted. This is particularly true for GWWs with agricultural traffic. These are used by farmers as access to their fields. Bulk density was measured on the GBS and GWW where rainfall simulations had been carried out. They reach $1.50 \pm 0.05 \mathrm{~g} . \mathrm{cm}^{-3}$ in GBS and $1.59 \pm 0.06 \mathrm{~g} . \mathrm{cm}^{-3}$ in GWW. These values are very high in comparison with mean bulk densities measured for cropland $\left(1.43 \pm 0.1 \mathrm{~g} . \mathrm{cm}^{-3}\right)$ and grassland $\left(1.29 \pm 0.05{\mathrm{~g} . \mathrm{cm}^{-3}}^{-3}\right)$ in the Belgian loess belt (Goidts and van Wesemael, in press).

GBSs and GWWs are generally known to reduce runoff, sediments and pollutants from cultivated areas (Fiener and Auerswald, 2003a; Le Bissonnais et al., 2004). Previous studies concluded that the infiltration capacity of grassed buffer strips is higher than that of arable land. Runoff reinfiltration in GBSs 
and GWWs is however very variable (10-91\%) depending on the experimental conditions and the rainfall characteristics (Mersie et al., 2003; Le Bissonnais et al., 2004; Vianello et al., 2005). GWWs are generally wider than GBSs and are installed in thalwegs. According to research conducted between 1994 and 2001 on a 290 m-long and 37 m-wide GWW in Germany, runoff was reduced by $87 \%$ and sediment delivery by $93 \%$ (Fiener and Auerswald, 2005b). Our rainfall simulations show that the runoff coefficient of grassed areas with heavy agricultural traffic is higher than that of cultivated fields (Table 4). Grassed areas have hence a more important role in reducing sediment concentration than in enhancing infiltration. Furthermore, they lead to a decrease in runoff velocity because of their high hydraulic roughness (Fiener and Auerswald, 2003a; Prosser et al., 1995; Fiener and Auerswald, 2003b, 2005a). Sedimentation is thus likely to occur. The subsequent decrease of peak discharge also reduces the flood risk in the downstream villages (Evrard et al., 2007b).

Runoff generation is very heterogeneous in orchards. Three soil surface states having a different behaviour can be distinguished (Fig. 5). Runoff is first of all generated on grassed wheel tracks (runoff coefficient of $78 \pm 5 \%$ ), given the high soil compaction. Infiltrability is higher on the grassed rows between trees (runoff coefficient of $33 \pm 9 \%$ ). In contrast, runoff has not been observed on the tilled soil under the trees and is unlikely to occur, given the high roughness and the absence of a crust.

\subsection{Comparison of measured runoff coefficients with other methods}

Evolution of the runoff coefficient for a $30 \mathrm{~mm}$-rainfall event throughout the year has been calculated for winter wheat and sugar beet (Fig. 6). The runoff coefficient on a winter wheat field is at its maximum in winter (Fig. 6a). Runoff coefficients calculated based on the tables of Cerdan et al. (2001) and the CN method adapted by Van Oost (2003) follow the same evolution as the ones obtained during our rainfall simulations. However, runoff coefficients obtained based on Cerdan et al. (2001) are overestimated by $60 \%$ on average in spring and summer. For instance, for wheat in July (C3-F12-R1), Cerdan et al. (2001) estimated a runoff coefficient of $45 \%$, while we obtained a value of c. $15 \%$. This justifies the local parameterisation for central Belgium. Runoff coefficients calculated with the CN method adapted by Van Oost (2003) are very close to the ones measured during the rainfall simulations, except in autumn. This can be explained by the fact that the roughness parameter is not taken into account in Eq. 4. Runoff coefficient is hence incorrectly high in November and December, although the soils are quite rough (R2) and enable thereby much infiltration. 
In the case of sugar beet (Fig. 6b), runoff coefficients obtained with the three methods are in the same order of magnitude and follow a similar evolution throughout the year. Again, the coefficients calculated from the infiltration values proposed by Cerdan et al. (2001) overestimate runoff in summer.

Overall, runoff coefficients measured during the rainfall simulations are consistent with the ones obtained with the two other methods. However, our results show the necessity to derive data valid for the local conditions even if similar studies are available for other regions located within the European loess belt (e.g. Le Bissonnais et al., 2005). The importance of soil surface roughness to explain runoff triggering is also demonstrated.

\subsection{Estimation of runoff risk at the field and catchment scales and implica-}

tions for muddy flood triggering

Monthly evolution of mean infiltration rates has been calculated for winter crops and summer crops, based on the 4-years monitoring of the 6 ha-field. The measurements obtained on $0.5 \mathrm{~m}^{2}$ plots and the 6-ha field remain in the same order of magnitude and are very well correlated (Pearson's correlation coefficient of 0.94 , Fig. 7). This homogeneity is explained by homogeneous soil surface characteristics and farming practices at the field scale, confirming the results obtained in a former study carried out in the European loess belt (Cerdan et al., 2004). However, on average, infiltration rates derived from the results of the rainfall simulations are $25 \%$ higher than field measurements (Fig. 7). This effect is explained by runoff transmission losses. With increasing plot length, runoff flow depth increases due to upslope runoff accumulation, submerging a larger area downslope (Dunne et al., 1991; Joel et al., 2002). Furthermore, there is an increasing probability of observing preferential infiltration pathways (cracks, macropores) with increasing plot size (Le Bissonnais et al., 1998).

Runoff generation risk has been evaluated for common crops in central Belgium based on the monthly surveys of soil surface characteristics (Table 5a). Risk classes have been defined based on infiltration rates measured at the field scale (Table 5b). For the combinations of soil surface characteristics containing at least one of the three parameters whereby runoff was never observed during the rainfall simulations (F0, R3, R4), an infiltration rate higher than $60 \mathrm{~mm} \cdot \mathrm{h}^{-1}$ has been attributed. Crops with a high risk are mainly observed between May and September (sugarbeet, maize, potatoes). It coincides with the period when rainfall intensity is at its highest in central Belgium (Verstraeten et al., 2006). 
Large quantities of runoff can then be generated when a heavy rainfall event occurs. High risk is also observed on bare and crusted soils in February, but it is unlikely to observe large quantities of runoff because of low intensity rainfall.

An index of runoff risk can be calculated at the catchment scale, taking the relative surface covered by the different crops into account (Eq.5).

$$
I_{C A T C H M E N T}=1 / A \sum_{i} I_{R U N O F F i} \cdot S_{i}
$$

6 Where $I_{C A T C H M E N T}$ is the runoff risk at the catchment scale, A is the catch7 ment area (ha), $I_{R U N O F F i}$ is the runoff risk of the crop $i$ given in Table $5 \mathrm{~b}, S_{i}$ 8 is the area of catchment cropland surface (ha) covered by the crop $i$. Runoff 9 risk classification at the catchment scale is given in Table 5b.

Runoff risk has been mapped for the fields of the Sint-Truiden catchment (Fig. 8). Mean runoff risk index for the entire catchment reached 2 (high risk) in May 2002, while it equalled 1.5 (medium risk) in May 2006. Furthermore, high risk fields were concentrated in the lower part of the catchment in May, 2002 (Fig. 8a). A muddy flood affected the village after a thunderstorm on May 9. The situation observed in May, 2006 is very different (Fig. 8b). Fields with a high risk are less numerous and evenly distributed, and a grassed waterway has been installed in the catchment thalweg. The GWW has been classified as a low risk area, given its high potential to slow down runoff (Fiener and Auerswald, 2005a; Evrard et al., 2007b). Even though several thunderstorms occurred with a rainfall intensity and duration similar to 2002, no muddy flood affected the village downstream.

Monthly distribution of heavy rainfall and runoff events has been plotted for the hillslope and catchment databases (Fig. 9). Given these datasets cover 4 and 5 years respectively (Table 1), we assume that the effect of crop rotation is taken into account (Table 7). It appears from Fig. 9 that most runoff events have been recorded between May and September $(60 \%$ in Walhain and $68 \%$ in Velm). This confirms the runoff risk classification at the field scale (Table 5c). The rather high number of runoff events recorded during Winter in Walhain is explained by very wet winter months in 2001 and 2002. This situation caused the generation of saturation overland flow. This finding is in agreement with former studies carried out in the Netherlands (Kwaad, 1991; Van Dijk and Kwaad, 1996). However, the saturation flow produced by long-duration rainfall of low intensity was distributed over entire days. Large quantities of runoff must be generated over a much shorter period to generate a muddy flood (Boardman et al., 2006). This situation occurs after local convective thunderstorms in spring and summer (Fig. 9). This is illustrated by the monthly distribution of mean runoff volumes and peak discharges recorded at the outlet of the 16ha-hillslope (Fig. 10). The largest quantities of runoff and the highest peak discharges are recorded between May and August. This is 


\section{Conclusions}

consistent with the muddy flood data available for central Belgium, showing that $90 \%$ of floods are recorded between May and September (Vandaele and Poesen, 1995; Verstraeten and Poesen, 1999; Evrard et al., 2007a).

${ }_{5}$ The simulation of a heavy rainfall event $\left(60 \mathrm{~mm} \cdot \mathrm{h}^{-1}\right.$ during 30 minutes $)$ has 6 been carried out on 17 representative combinations of soil surface characteris7 tics (crop cover, surface crusting and roughness) throughout the year, as well 8 as on maize lines and on wheel tracks. Runoff has been observed in 10 cases 9 only, rainfall infiltrating completely in the case of (ploughed) bare soils that - are not yet crusted and soils with a dense crop cover, a moderate roughness 1 and an incomplete crust. The highest runoff coefficients have been observed for 12 wheel tracks $(95 \pm 3 \%)$ and fields with maize lines in May and June $(90 \pm 3 \%)$. 3 In May and June, sugar beet as well as crusted soils with a dense crop cover 14 also generate runoff (mean runoff coefficients of 57 and $58 \%$, respectively). 15 Overall, grassed areas have a higher runoff coefficient $(63 \%$ for GWWs and $72 \%$ for GBSs, on average) than cultivated fields (13-58\% on average).

The obtained database allows parameterising erosion and runoff models (e.g. STREAM). Such an expert-based model requires a local calibration and validation. The different values obtained in this study in comparison with the ones observed in Normandy justify the local parameterisation and the use of a portable rainfall simulator in the field. Measurements obtained thanks to rainfall simulations on $0.5 \mathrm{~m}^{2}$-plots can be used to estimate runoff generation at the field scale. A runoff risk classification has been applied to common crops in central Belgium. It is shown that February as well as the period between May and September are the most critical months for runoff generation at the field scale. However, runoff monitoring at the catchment scale shows that muddy floods are most likely to occur between May and September. During this period, local convective thunderstorms producing large quantities of hortonian runoff over a short period on fields with a high runoff risk (e.g. maize, sugarbeet, potatoes) occur. 


\section{Acknowledgements}

2 The remarks of two anonymous referees greatly improved the manuscript.

3 The authors also want to thank Marco Bravin for the construction of the

4 simulator and his technical assistance during the experiments. The farmers

5 are also acknowledged for allowing to carry out the simulations in their fields.

\section{References}

Beven, K., 2001. Rainfall - Runoff modelling. The primer. Wiley, Chichester. Bielders, C., Ramelot, C., Persoons, E., 2003. Farmer perception of runoff and erosion and extent of flooding in the silt-loam belt of the Belgian Walloon Region. Environmental Science and Policy 6, 85-93.

Boardman, J., Evans, R., Ford, J., 2003. Muddy floods on the South Downs, southern England: problem and responses. Environmental Science and Policy $6,69-83$.

Boardman, J., Ligneau, L., De Roo, A., Vandaele, K., 1994. Flooding of property by runoff from agricultural land in northwestern Europe. Geomorphology 10, 183-196.

Boardman, J., Verstraeten, G., Bielders, C., 2006. Muddy floods. In: Boardman, J., Poesen, J. (Eds.), Soil erosion in Europe. Wiley, Chichester, pp. 743-755.

Bowyer-Bower, T., Burt, T., 1989. Rainfall simulators for investigating soil response to rainfall. Soil Technology 2, 1-16.

Bresson, L., Boiffin, J., 1990. Morphological characterisation of soil crust development stages on an experimental field. Geoderma 47, 301-325.

Cerdan, O., Couturier, A., Le Bissonnais, Y., Lecomte, V., Souchère, V., 2001. Incorporating soil surface crusting processes in an expert-based runoff model : Sealing and Transfer by Runoff and Erosion related to Agricultural Management. Catena 46, 189-205.

Cerdan, O., Le Bissonnais, Y., Govers, G., Lecomte, V., Van Oost, K., Couturier, A., King, C., Dubreuil, N., 2004. Scale effect on runoff from experimental plots to catchments in agricultural areas in Normandy. Journal of Hydrology 299, 4-14.

De Roo, A., Wesseling, C., Ritsema, C., 1996. LISEM : a single-event physically based hydrological and soil erosion model for drainage basins. I. Theory, input and output. Hydrological processes 10, 1107-1117.

Delbeke, L., 2001. Extreme neerslag in Vlaanderen. (In Dutch) - Technical report. Ministerie van de Vlaamse Gemeenschap, afdeling Water, Brussels.

Dunne, T., Zhang, W., Aubry, B., 1991. Effects of rainfall, vegetation and 
microtopography on infiltration and runoff. Water Resources Research 27, 2271-2285.

Evrard, O., Bielders, C., Vandaele, K., van Wesemael, B., 2007a. Spatial and temporal variation of muddy floods in central Belgium, off-site impacts and potential control measures. Catena 70, 443-454.

Evrard, O., Persoons, E., Vandaele, K., van Wesemael, B., 2007b. Effectiveness of erosion mitigation measures to prevent muddy floods : A case study in the Belgian loam belt. Agriculture Ecosystems and Environment 118, 149-158.

Fiener, P., Auerswald, K., 2003a. Concepts and effects of a multi-purpose grassed waterway. Soil Use and Management 19, 65-72.

Fiener, P., Auerswald, K., 2003b. Effectiveness of grassed waterways in reducing runoff and sediment delivery from agricultural watersheds. J. Environ. Qual. 32, 927-936.

Fiener, P., Auerswald, K., 2005a. Measurement and modelling of concentrated runoff in grassed waterways. Journal of Hydrology 301, 198-215.

Fiener, P., Auerswald, K., 2005b. Seasonal variation of grassed waterway effectiveness in reducing runoff and sediment delivery from agricultural watersheds in temperate Europe. Soil Tillage Research 87 (1), 48-58.

Goidts, E., van Wesemael, B., in press. Regional assessment of soil organic carbon changes under agriculture in southern Belgium (1955-2005). Geoderma.

Hufty, A., 2001. Introduction à la climatologie. (In French). De Boeck Université, Brussels.

Joel, A., Messing, I., Seguel, O., Casanova, M., 2002. Measurement of surface water runoff from plots of two different sizes. Hydrological Processes 16, 1467-1478.

Kwaad, F., 1991. Summer and winter regimes of runoff generation and soil erosion on cultivated soils (The Netherlands). Earth Surface Processes and Landforms 16, 653-662.

Lamandé, M., Hallaire, V., Curmi, P., Pérès, G., Cluzeau, D., 2003. Changes of pore morphology, infiltration and earthworm community in a loamy soil under different agricultural managements. Catena 54, 637-649.

Le Bissonnais, Y., Benkhadra, H., Chaplot, V., Fox, D., King, D., Daroussin, J., 1998. Crusting, runoff and sheet erosion on silty loamy soils at various scales and upscaling from $\mathrm{m} 2$ to small catchments Crusting, runoff and sheet erosion on silty loamy soils at various scales and upscaling from $\mathrm{m} 2$ to small catchments. Soil and Tillage Research 46 (1-2), 69-80.

Le Bissonnais, Y., Cerdan, O., Lecomte, V., Benkhadra, H., Souchère, V., Martin, P., 2005. Variability of soil surface characteristics influencing runoff and interrill erosion. Catena 62, 111-124.

Le Bissonnais, Y., Lecomte, V., Cerdan, O., 2004. Grass strip effects on runoff and soil loss. Agronomie 24, 129-136.

Léonard, J., Ancelin, O., Ludwig, B., Richard, G., 2006. Analysis of the dynamics of soil infiltrability of agricultural soils from continuous rainfallrunoff measurements on small plots. Journal of Hydrology 326 (1-4), 122- 
134.

Mersie, W., Seybold, C., Mc Namee, C., M.A., L., 2003. Abating endosulfan from runoff using vegetative filter strips: the importance of plant species and flow rate. Agriculture Ecosystems and Environment 97, 215-223.

Morgan, R., 1995. Soil erosion and conservation, 2nd Edition. Longman, Harlow.

Onstad, C., 1984. Depressional storage on tilled soil surfaces. Transactions of the ASAE 27, 729-732.

Pan, C., Shangguan, Z., 2006. Runoff hydraulic characteristics and sediment generation in sloped grassplots under simulated rainfall conditions. Journal of Hydrology 331 (1-2), 178-185.

Prosser, I., Dietrich, W., Stevenson, J., 1995. Flow resistance and sediment transport by concentrated overland flow in a grassland valley. Geomorphology 13, 71-86.

Römkens, M., Luk, S., Poesen, J., Mermut, A., 1995. Rain infiltration into loess soils from different geographic regions. Catena 25, 21-32.

Rommens, T., Verstraeten, G., Bogman, P., Peeters, I., Poesen, J., Govers, G., Van Rompaey, A., Lang, A., 2006. Holocene alluvial sediment storage in a small river catchment in the loess area of central Belgium. Geomorphology $77,187-201$.

Schröder, R., Auerswald, K., 2000. Modellierung des Jahresgangs der Verschlämmungsinduzierten Abflussbildung in kleinen, landwirtschaftlich genutzten Einzugsgebieten. (In German). Zeitschrift für Kulturtechnik und Landentwicklung 41, 167-172.

Selby, M., 1993. Hillslope materials and processes, 2nd Edition. Oxford University Press, Oxford.

Souchère, V., King, C., Dubreuil, N., Lecomte-Morel, V., Le Bissonnais, Y., Chalat, M., 2003. Grassland and crop trends: role of the European Union Common Agricultural Policy and consequences for runoff and soil erosion. Environmental Science and Policy 6, 7-16.

Statistics Belgium, 2006.

URL http://www. statbel.fgov.be/

USDA-SCS, 1973. A method for estimating volume and rate of runoff in small watersheds - Technical report. No. 149.

Valentin, C., Bresson, L., 1992. Morphology, genesis and classification of surface crusts in loamy and sandy soils. Geoderma (55), 225-245.

Van Dijk, P., Kwaad, F., 1996. Runoff generation and soil erosion in small agricultural catchments with loess-derived soils. Hydrological Processes (10), 1049-1059.

Van Oost, K., 2003. Spatially distributed modelling of surface runoff. Unpublished PhD thesis, K.U. Leuven, Belgium.

Van Orshoven, J., Maes, J., Vereecken, H., Feyen, J., Didal, R., 1988. A structured database of Belgian soil profile data. Pédologie 38, 191-206.

Vandaele, K., Poesen, J., 1995. Spatial and temporal patterns of soil erosion rates in an agricultural catchment, central Belgium. Catena 25, 213-226. 
Verstraeten, G., Poesen, J., 1999. The nature of small-scale flooding, muddy floods and retention pond sedimentation in central Belgium. Geomorphology 29, 275-292.

Verstraeten, G., Poesen, J., Goossens, D., Gillijns, K., Bielders, C., Gabriels, D., Ruysschaert, G., Van Den Eeckhaut, M., Vanwalleghem, T., Govers, G., 2006. Belgium. In: Boardman, J., Poesen, J. (Eds.), Soil erosion in Europe. Wiley, Chichester, pp. 385-411.

Vianello, M., Vischetti, C., Scarponi, L., Zanin, G., 2005. Herbicide losses in runoff events from a field with a low slope: Role of a vegetative filter strip. Chemosphere 61, 717-725.

World Reference Base, 1998. World Reference Base for Soil Resources. FAO, World Resources report $\mathrm{n}^{\circ} 84$, Rome, Italy.

\section{$6 \quad$ Figure captions}

Figure 1. (a) Location of the study sites in Belgium; (b) Louvain-la-Neuve field (6 ha); (c) Walhain catchment (5 fields ; 16 ha); (d) Sint-Truiden catchment (58 fields and a grassed waterway - GWW; 300 ha).

Figure 2. Combination of soil surface characteristics for all observed fields $(\mathrm{n}=65)$ in 2005 . The classification of soil surface characteristics in given in Table 2.

Figure 3. Combination of soil surface characteristics for the observed fields $(\mathrm{n}=65)$ and for each season in 2005.

Figure 4. Relative importance of soil surface characteristics for runoff generation. Bars represent one standard deviation.

Figure 5. Different soil surface conditions in orchards $(\mathrm{A}=$ tilled soil under the trees; $\mathrm{B}=$ grassed wheel tracks; $\mathrm{C}=$ grassed rows between trees).

Figure 6. Evolution of runoff coefficient calculated after three methods for a 30 mm-rainfall event on (a) a winter wheat field and (b) a sugar beet field.

Figure 7. Comparison of infiltration rates obtained for monthly soil surface characteristics of fields planted with summer and winter crops based on (i) rainfall simulations and (ii) long-term monitoring of the 6 ha-field. Error bars represent one standard deviation.

Figure 8. Spatial distribution of runoff generation risk in the Sint-Truiden catchment. Risk estimated according to the distribution of crops as observed 
in (a) May, 2002 and (b) May, 2006.

Figure 9. Monthly distribution of the observed rainfall events with more than $15 \mathrm{~mm}$ of cumulative precipitation, and number of recorded runoff events in (a) Walhain hillslope and (b) Sint-Truiden catchment.

Figure 10. Monthly distribution of (a) mean runoff volumes $\left(\mathrm{m}^{3}\right)$ and (b) mean peak discharges $\left(1 . \mathrm{s}^{-1}\right)$ measured at the outlet of the 16ha-hillslope. Error bars represent the maximal range of measurements over the 4 year period. 


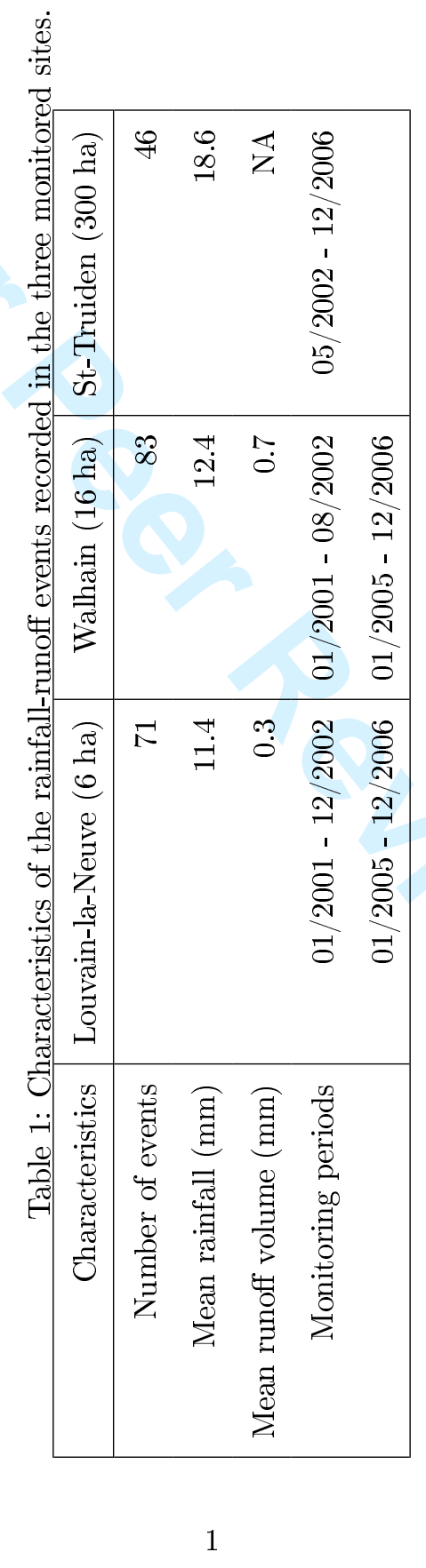

http://mc.manuscriptcentral.com/esp 
Table 2: Classification of soil surface characteristics according to Le Bissonnais et al., 2005.

(a) Classes of soil surface roughness. Roughness is defined as the difference in the heights of the deepest part of microdepressions and the lowest point of their divide.

\begin{tabular}{|l|l|}
\hline Grade & Roughness $(\mathrm{cm})$ \\
\hline R0 & $0-1$ \\
R1 & $1-2$ \\
R2 & $2-5$ \\
R3 & $5-10$ \\
R4 & $>10$ \\
\hline
\end{tabular}

(b) Classes of soil surface crusting.

\begin{tabular}{|l|l|}
\hline Notation & Description \\
\hline F0 & Initial fragmentary structure \\
F11 & Altered fragmentary state with structural crusts \\
F12 & Local appearance of depositional crusts \\
F2 & Continuous state with depositional crusts \\
\hline
\end{tabular}

(c) Classes of crop cover.

\begin{tabular}{|l|l|}
\hline Notation & Area covered by canopy or litter (\%) \\
\hline C 1 & From 0 to $20 \%$ \\
C 2 & From 21 to $60 \%$ \\
C 3 & From 61 to $100 \%$ \\
\hline
\end{tabular}




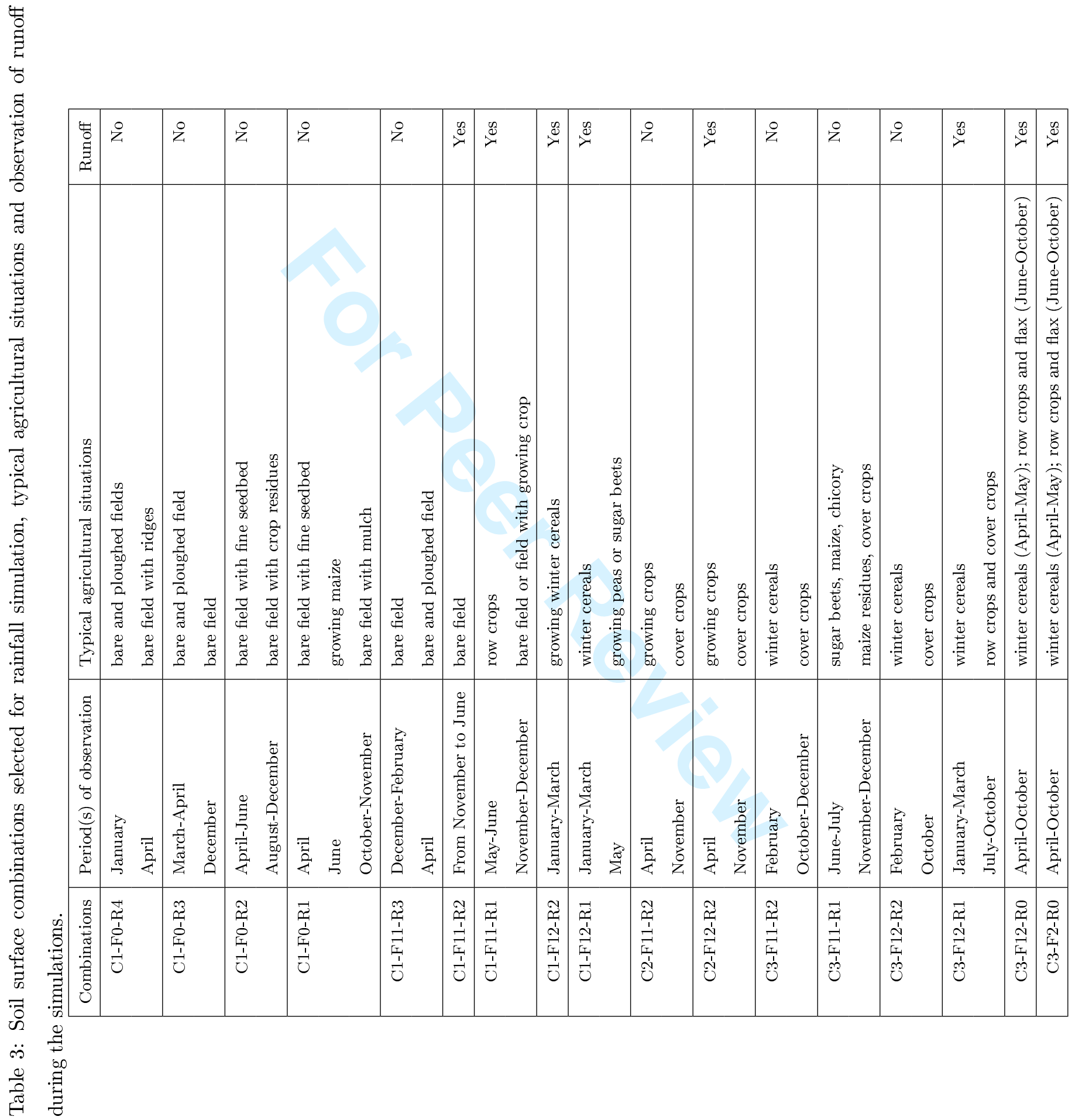




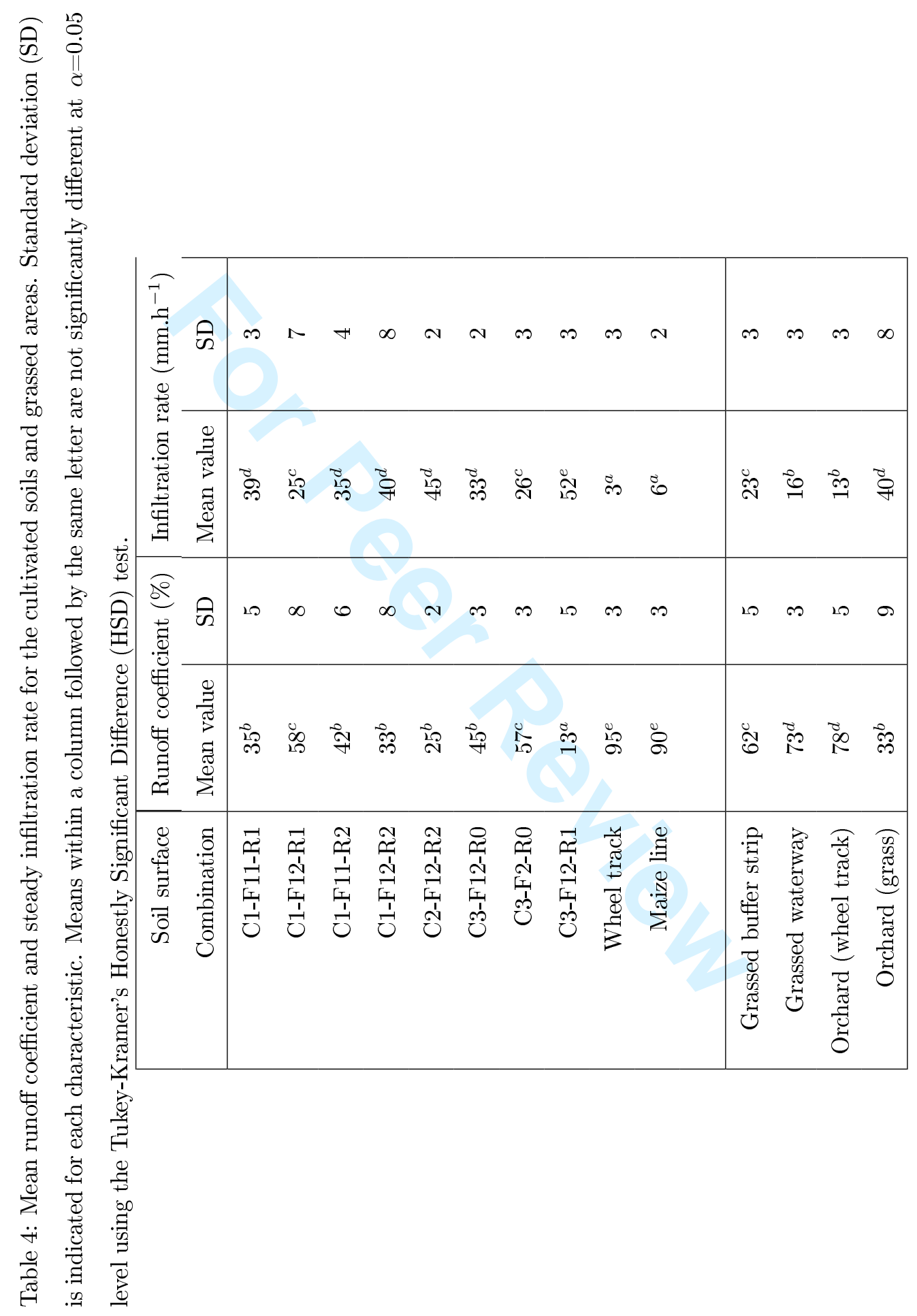


Table 6: Surface (\%) covered by the different crops in the Walhain and SintTruiden study sites.

\begin{tabular}{|r|rrrr|rrrrr|}
\hline & \multicolumn{3}{|c|}{ Walhain (16 ha) } & \multicolumn{5}{c|}{ Sint-Truiden (300 ha) } \\
\hline & 2001 & 2002 & 2005 & 2006 & 2002 & 2003 & 2004 & 2005 & 2006 \\
\hline Wheat & 26 & 74 & 55 & 37 & 11 & 44 & 38 & 38 & 37 \\
Flax & 0 & 0 & 0 & 0 & 0 & 16 & 6 & 4 & 14 \\
Sugarbeet & 0 & 26 & 34 & 35 & 46 & 16 & 20 & 34 & 32 \\
Maize & 74 & 0 & 11 & 8 & 21 & 1 & 10 & 2 & 0 \\
Potatoes & 0 & 0 & 0 & 20 & 16 & 12 & 8 & 14 & 7 \\
Other crops & 0 & 0 & 0 & 0 & 6 & 11 & 18 & 8 & 10 \\
\hline
\end{tabular}




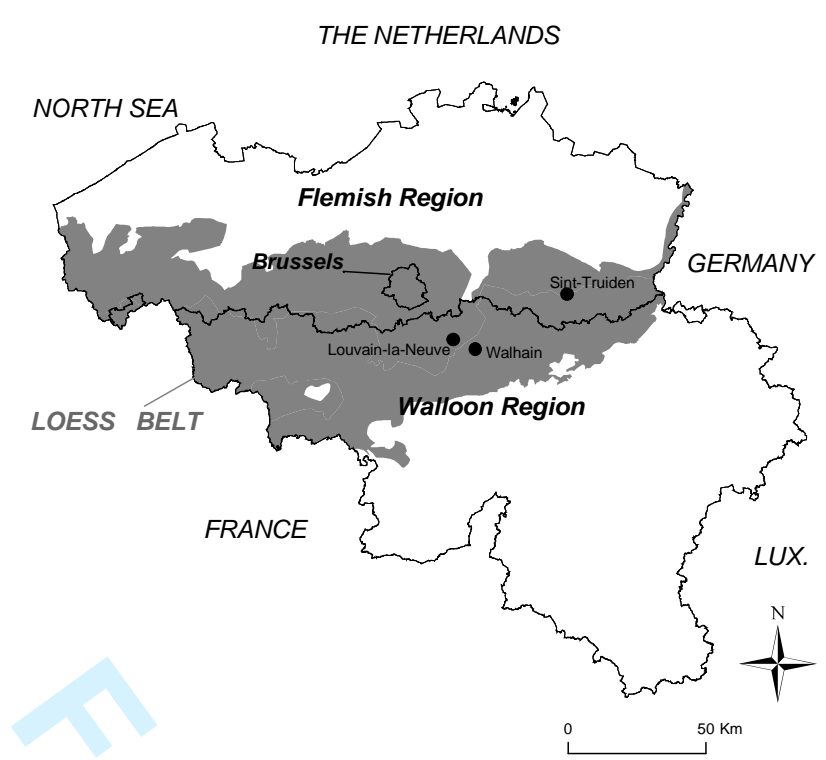

(a)

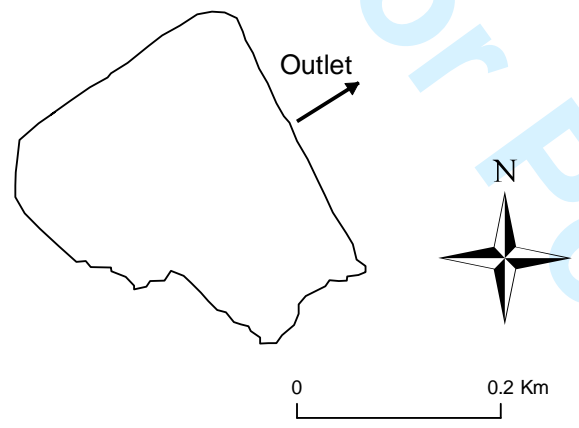

(b)

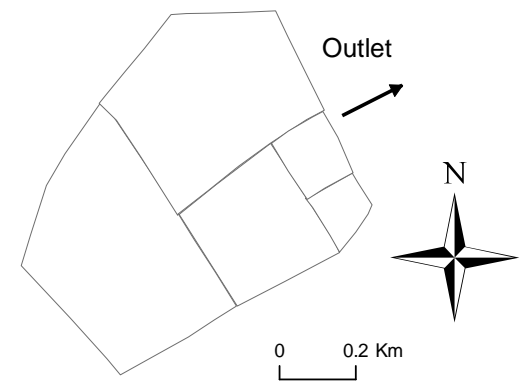

(c)

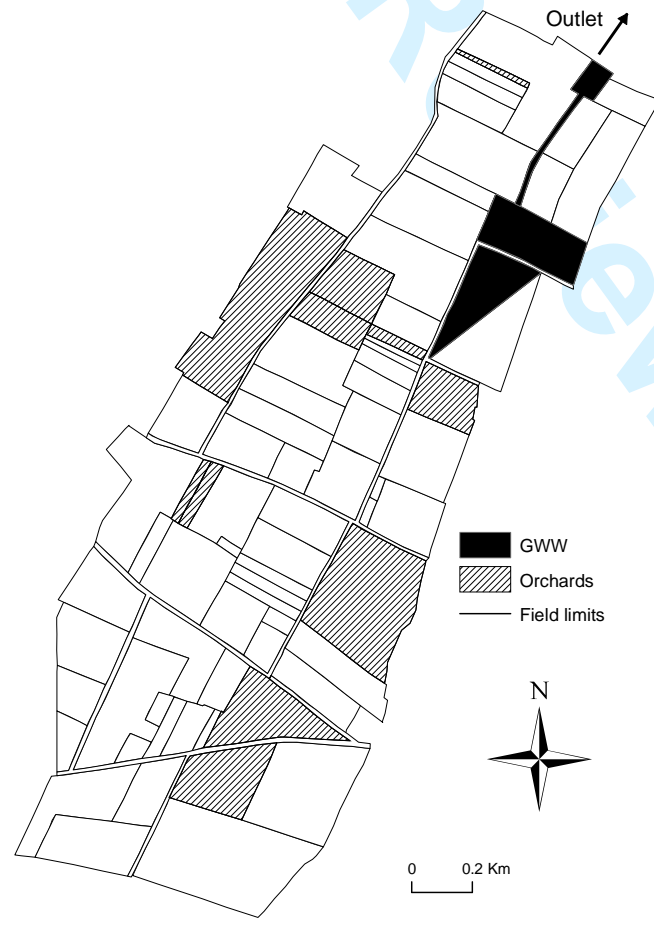

(d)

Figure 1 


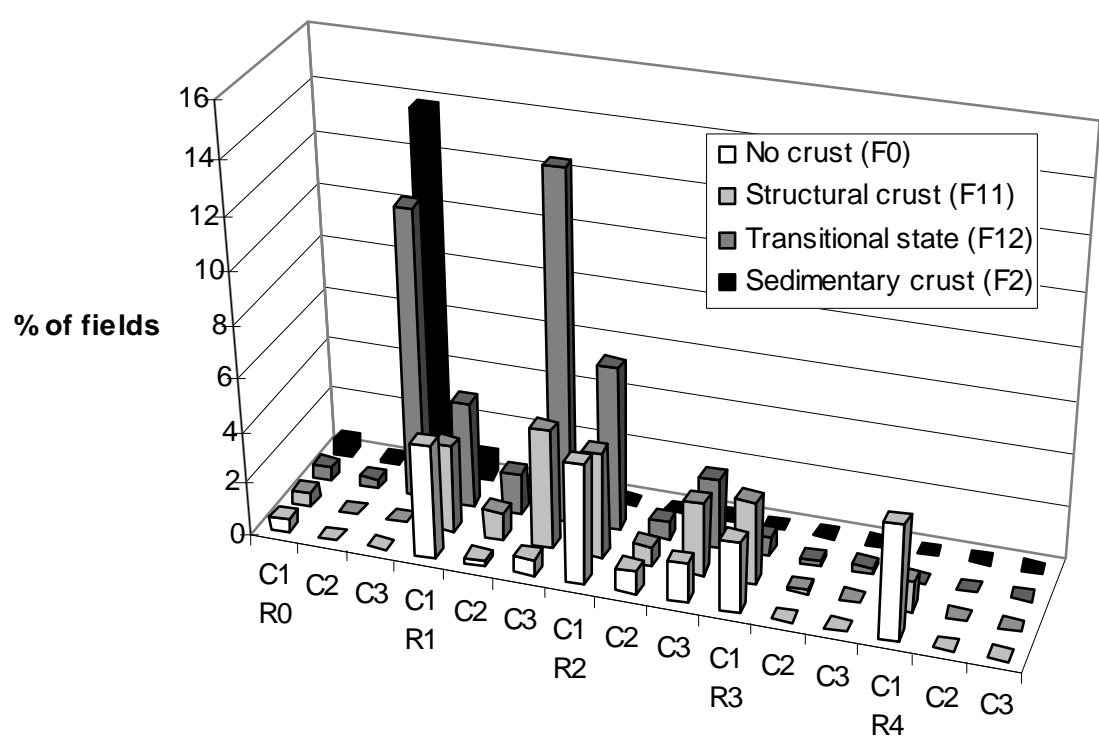

Soil roughness and crop cover

Figure 2 
$\%$ of fields

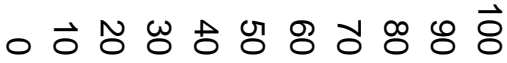

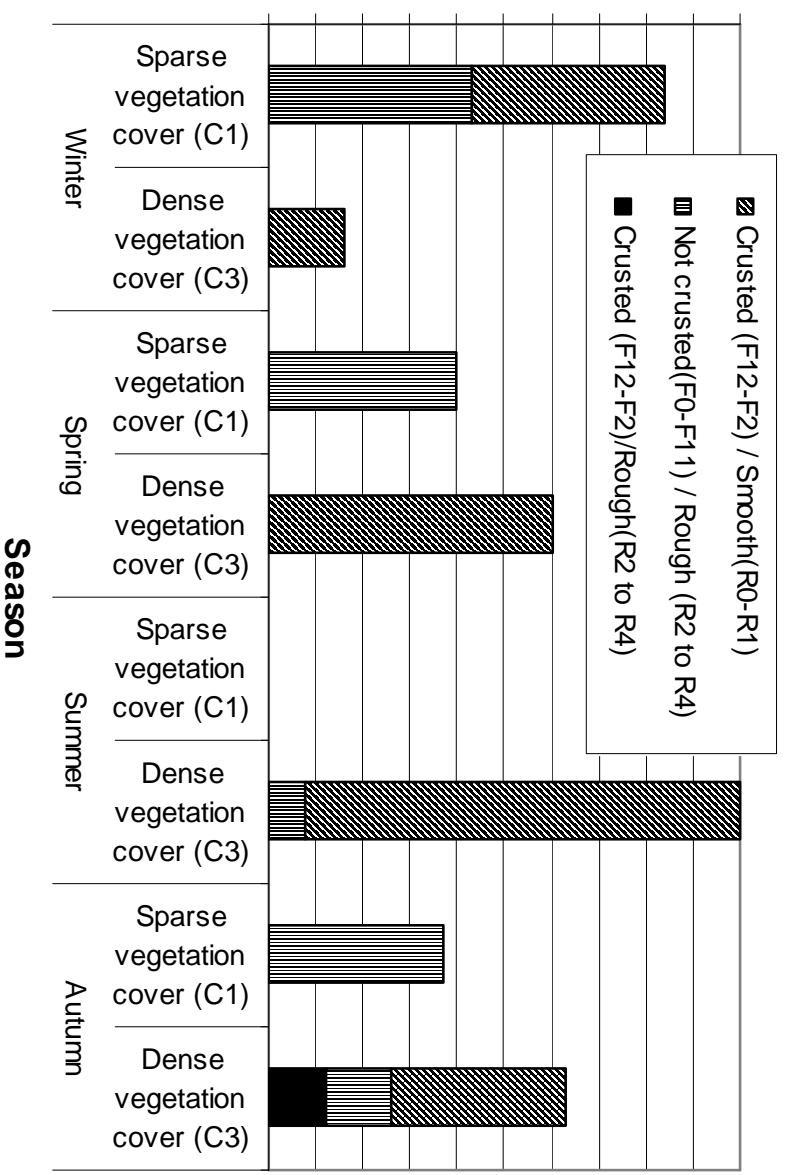




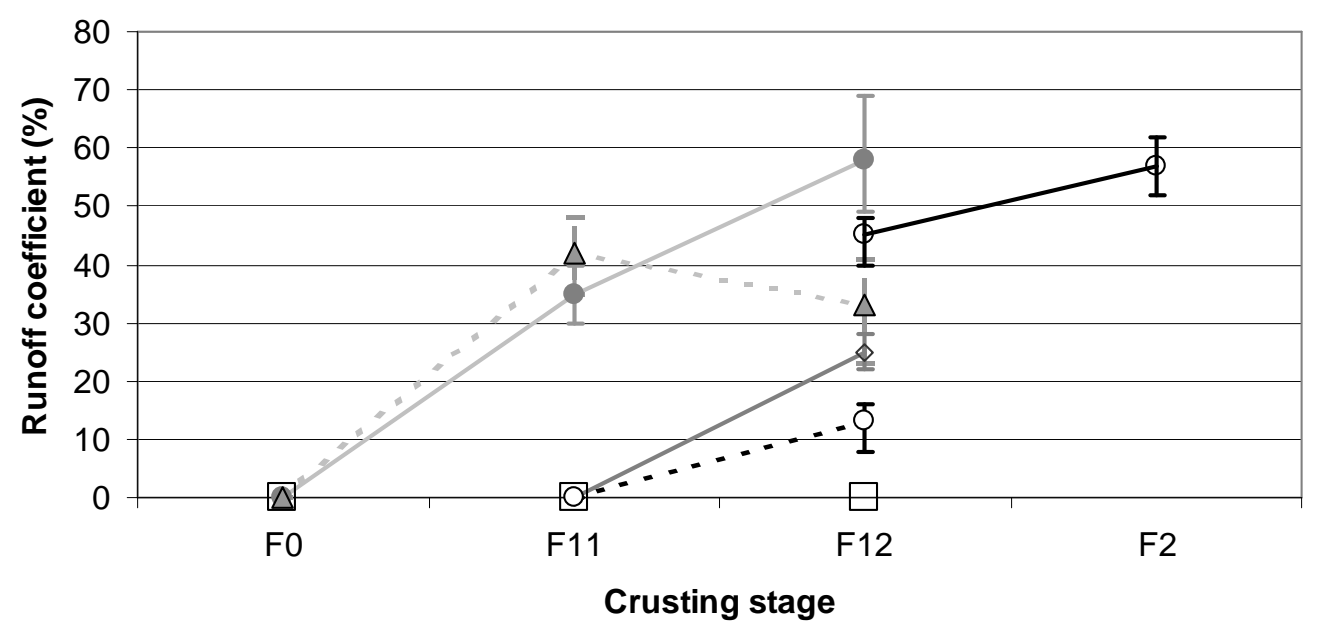

\begin{tabular}{|c|c|}
\hline$\square \quad \mathrm{C} 1-\mathrm{R} 0 /$ & $-\mathrm{C} 1-\mathrm{R} 1$ \\
\hline$\Delta=\mathrm{C} 1-\mathrm{R} 2$ & $\diamond \mathrm{C} 2-\mathrm{R} 2$ \\
\hline$-\mathrm{C} 3-\mathrm{R} 0$ & - -O - C3-R1 \\
\hline
\end{tabular}

Figure 4 


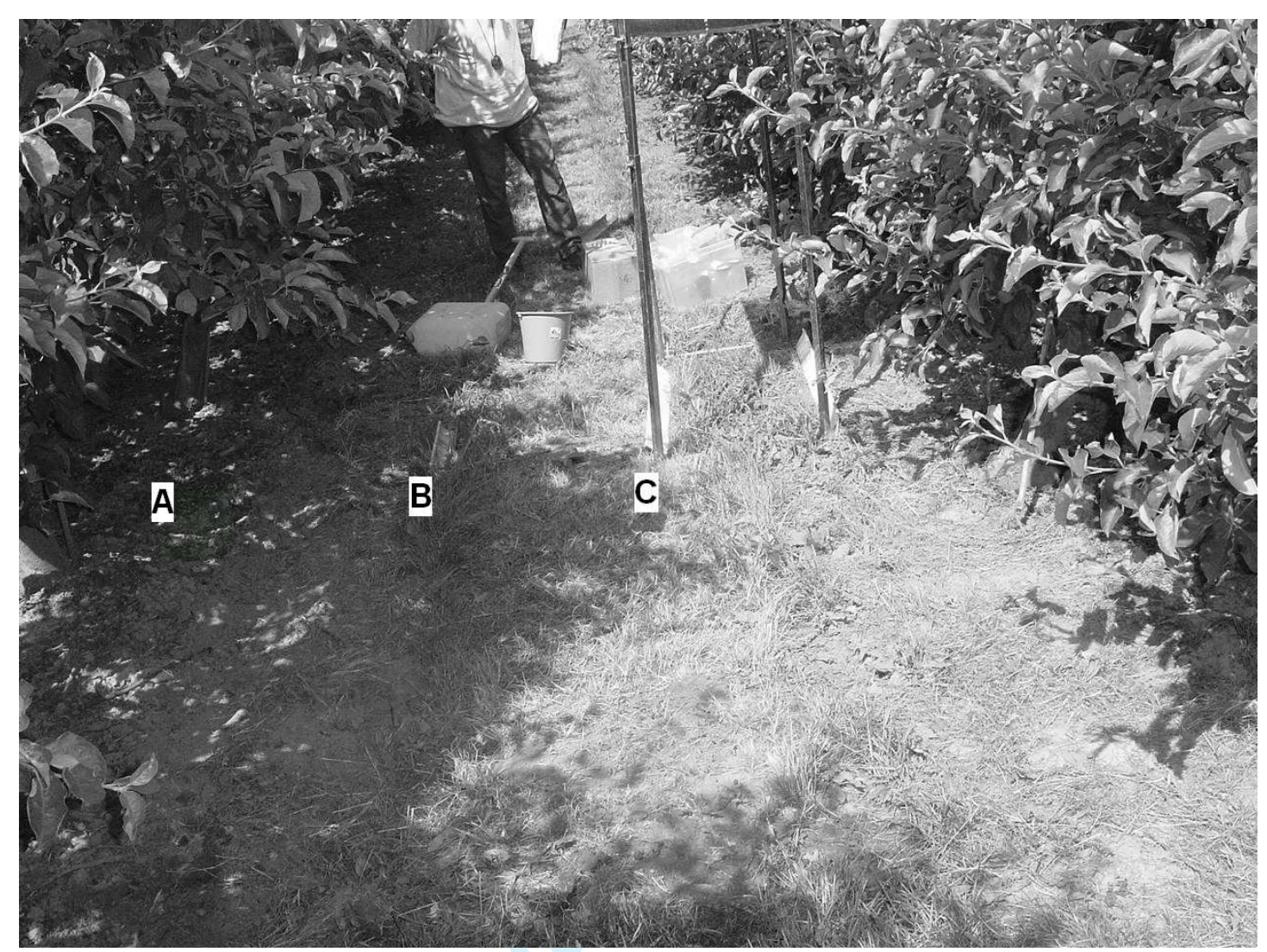

Figure 5 


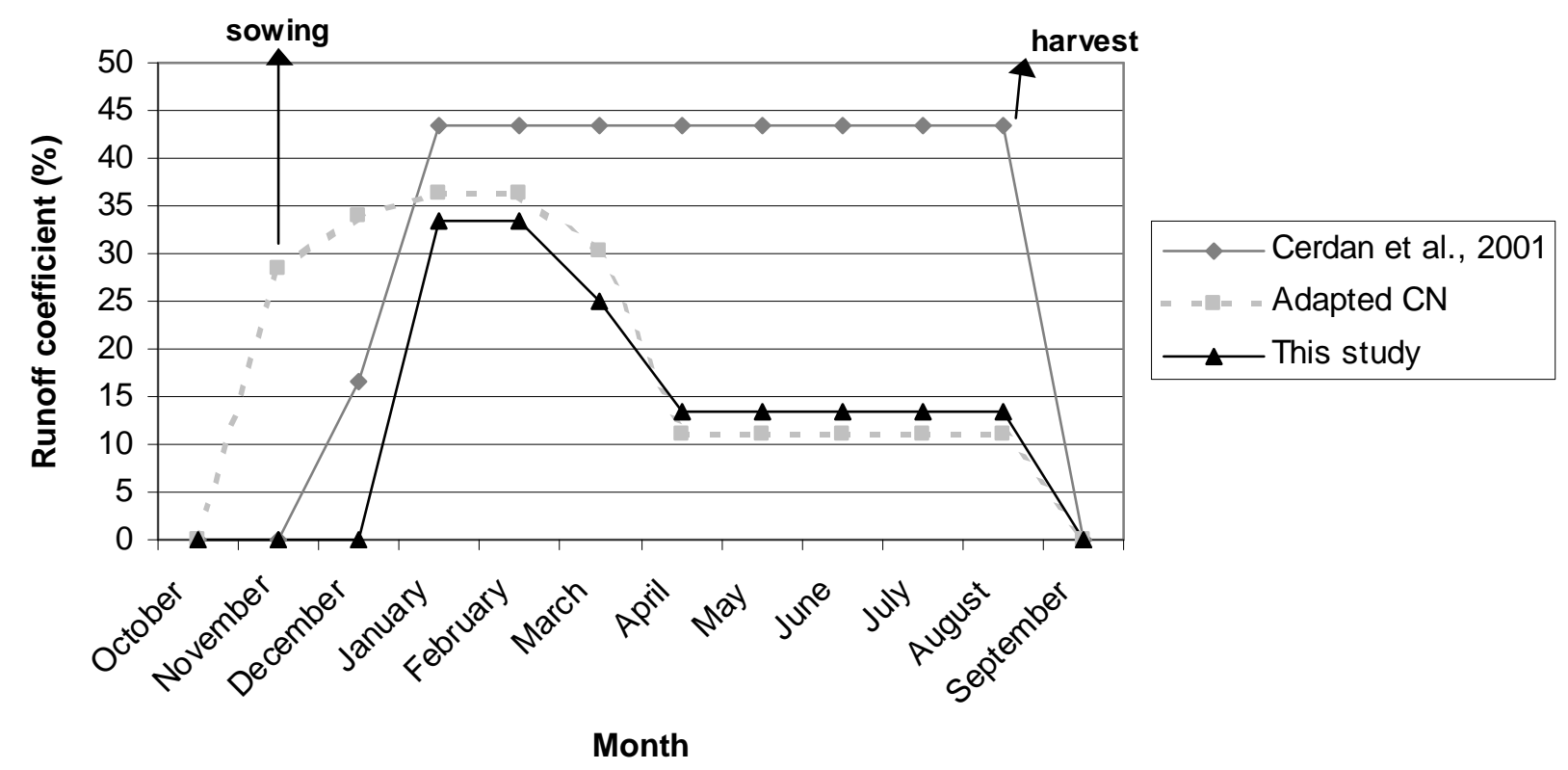

(a)

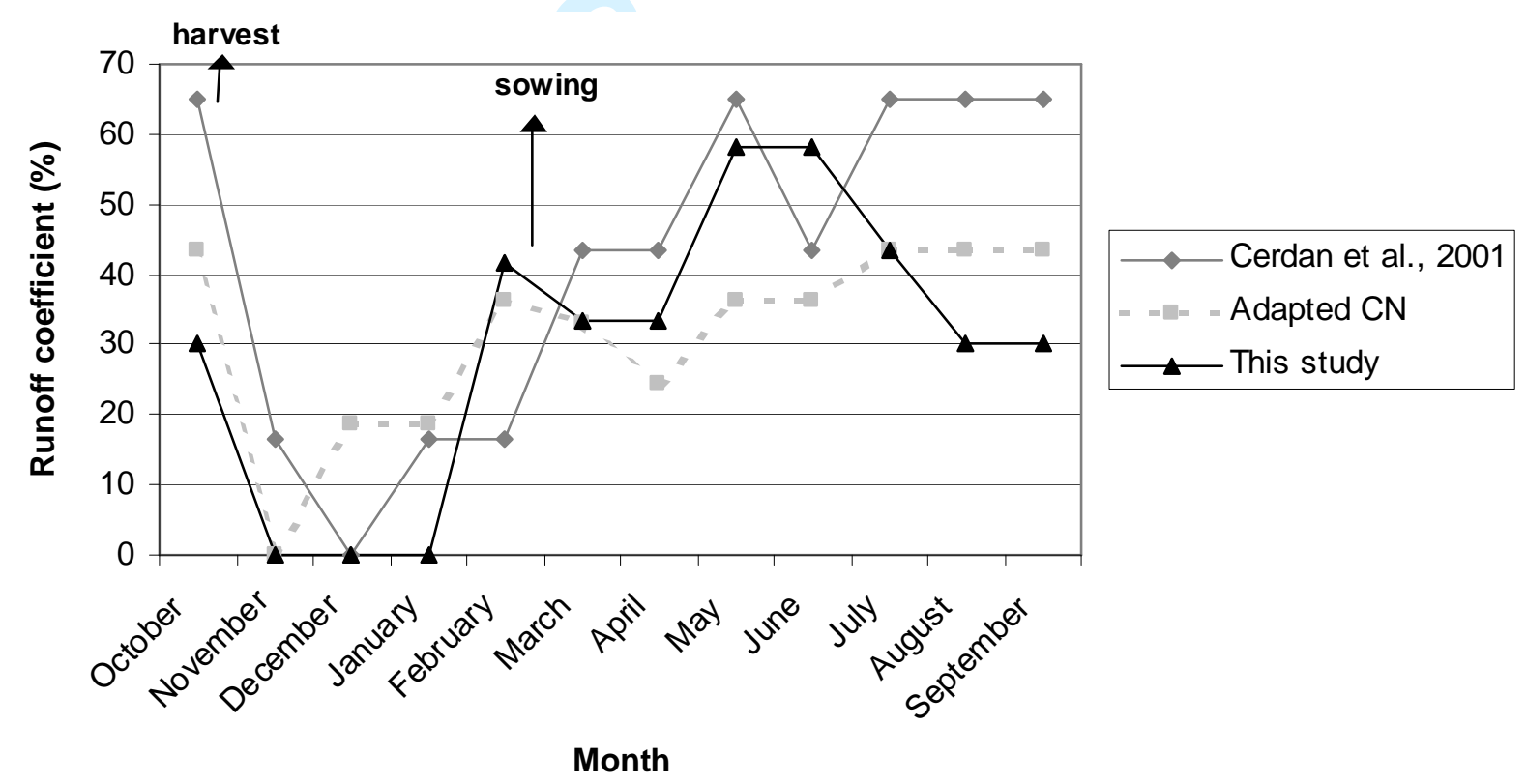

(b)

Figure 6 


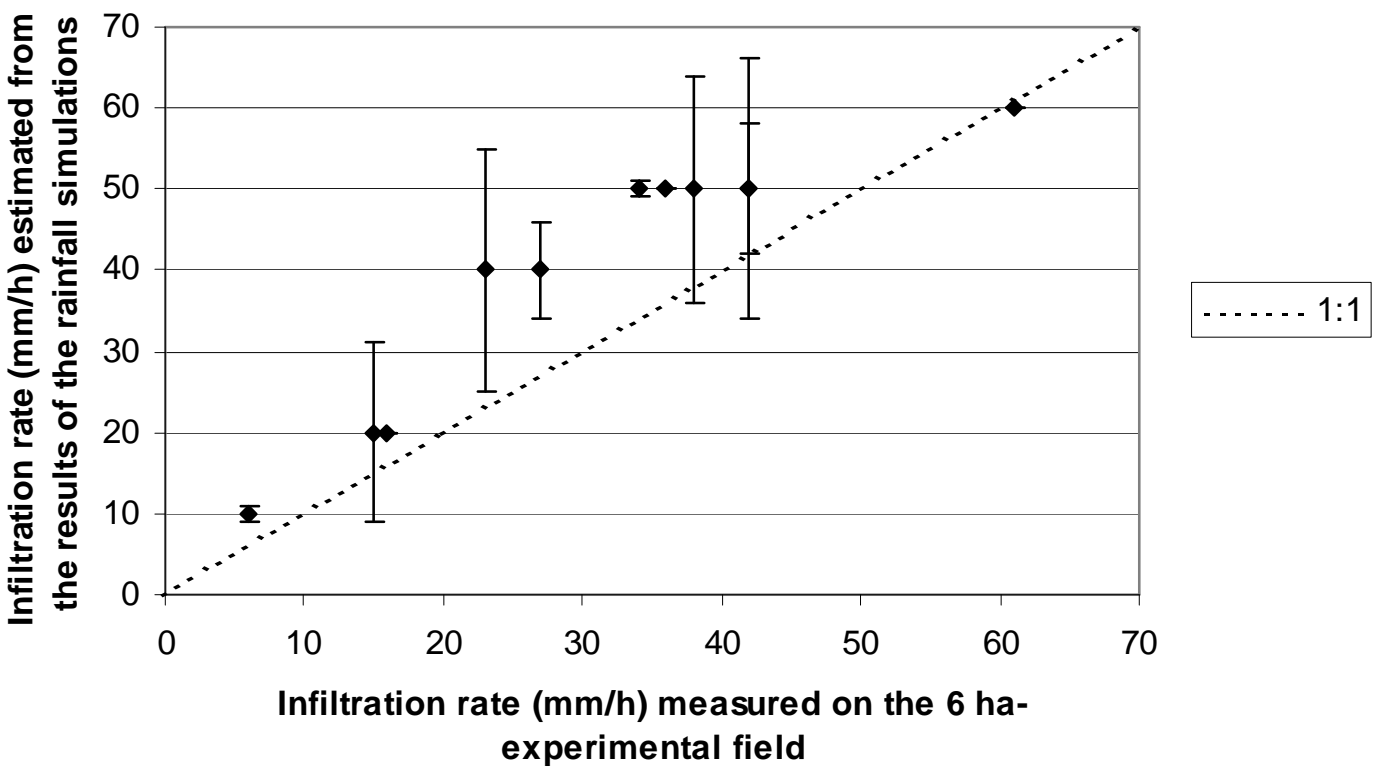

Figure 7 


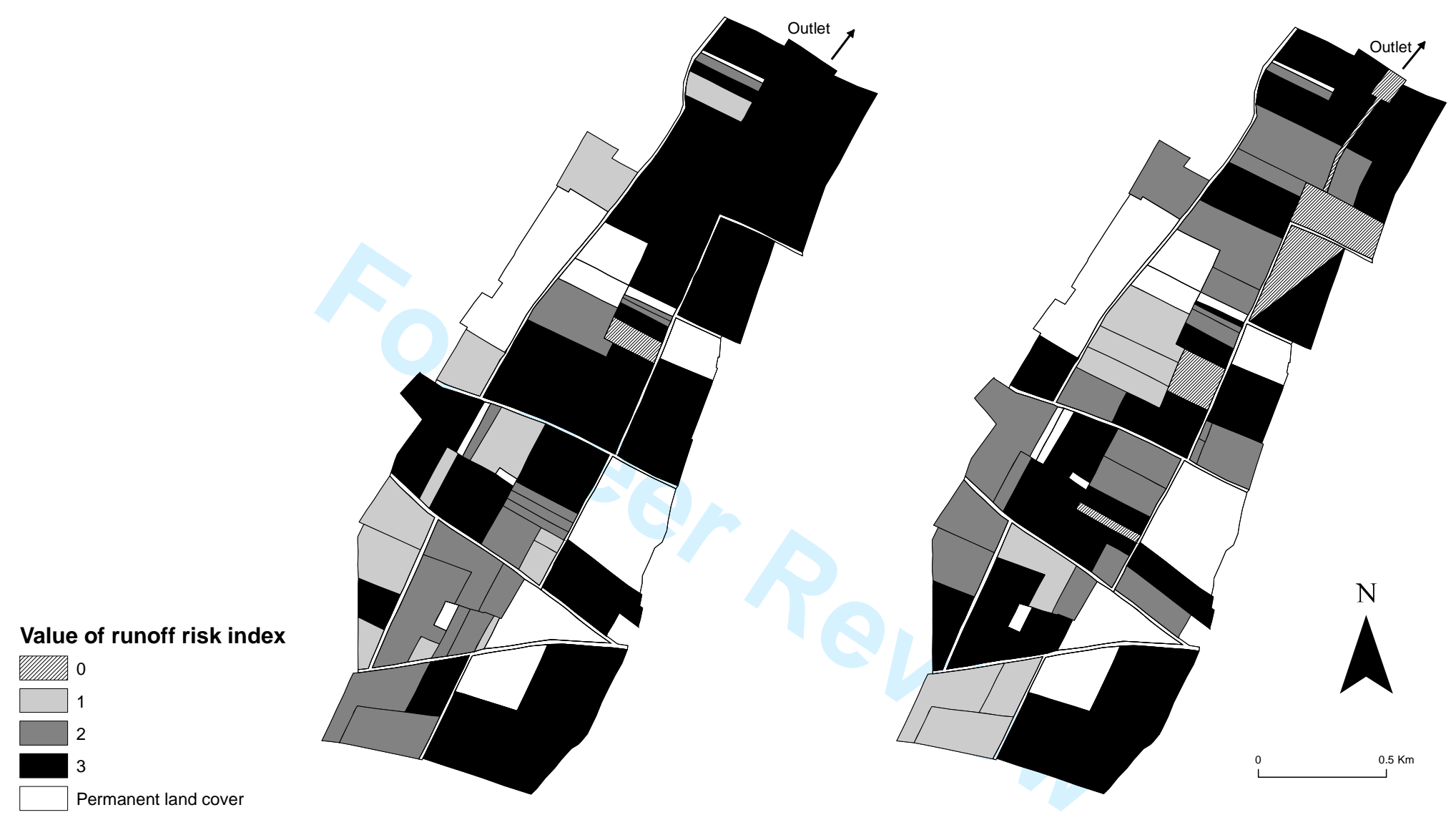

(a)

(b)

Figure 8 


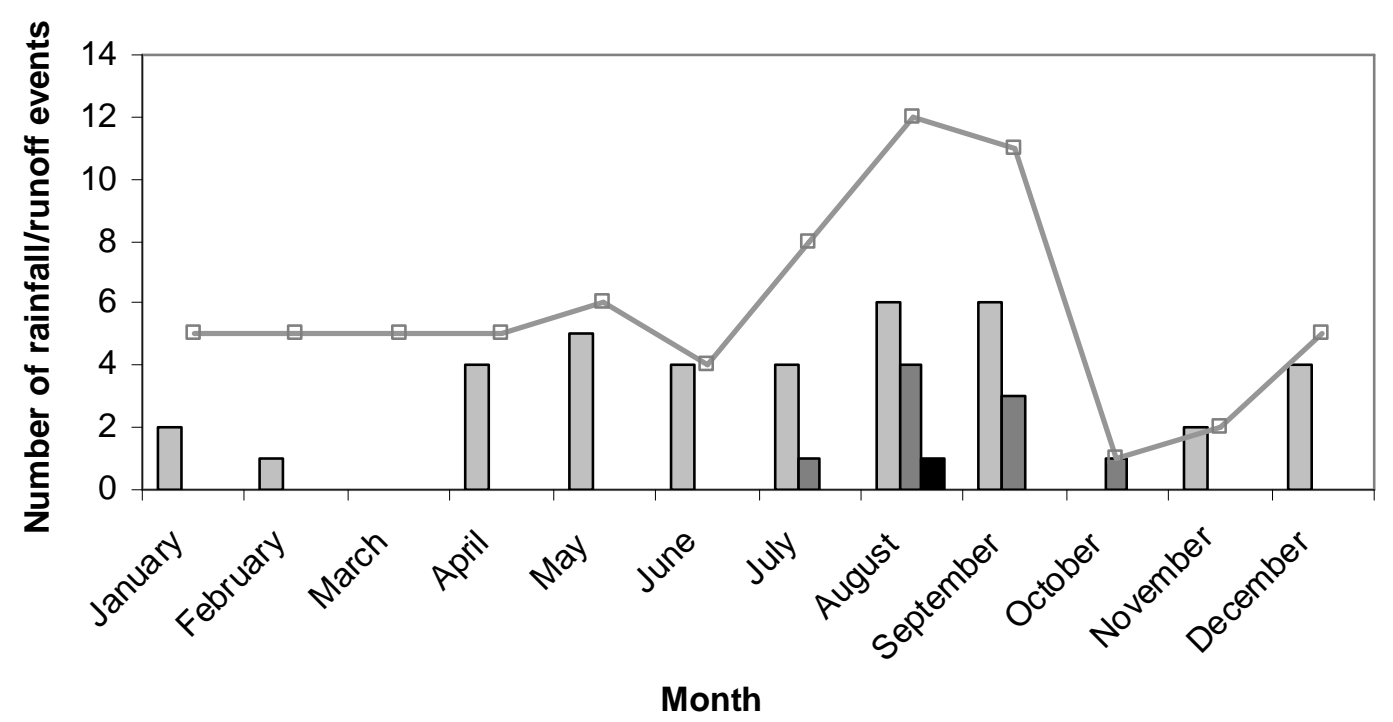

(a)

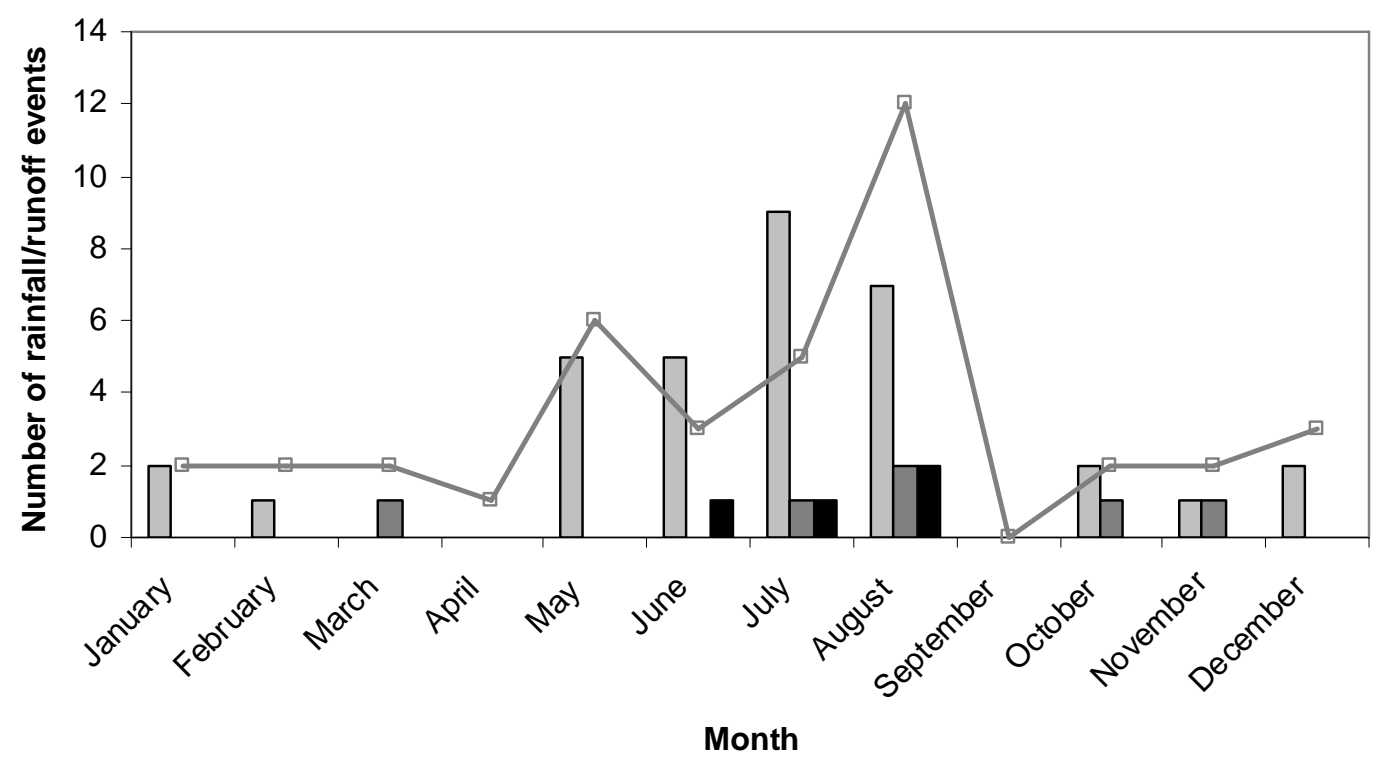

$\square 15-24 \mathrm{~mm} \square 25-34 \mathrm{~mm}$

$35 \mathrm{~mm}$ and more $\square$ Number of runoff events

(b)

Figure 9 


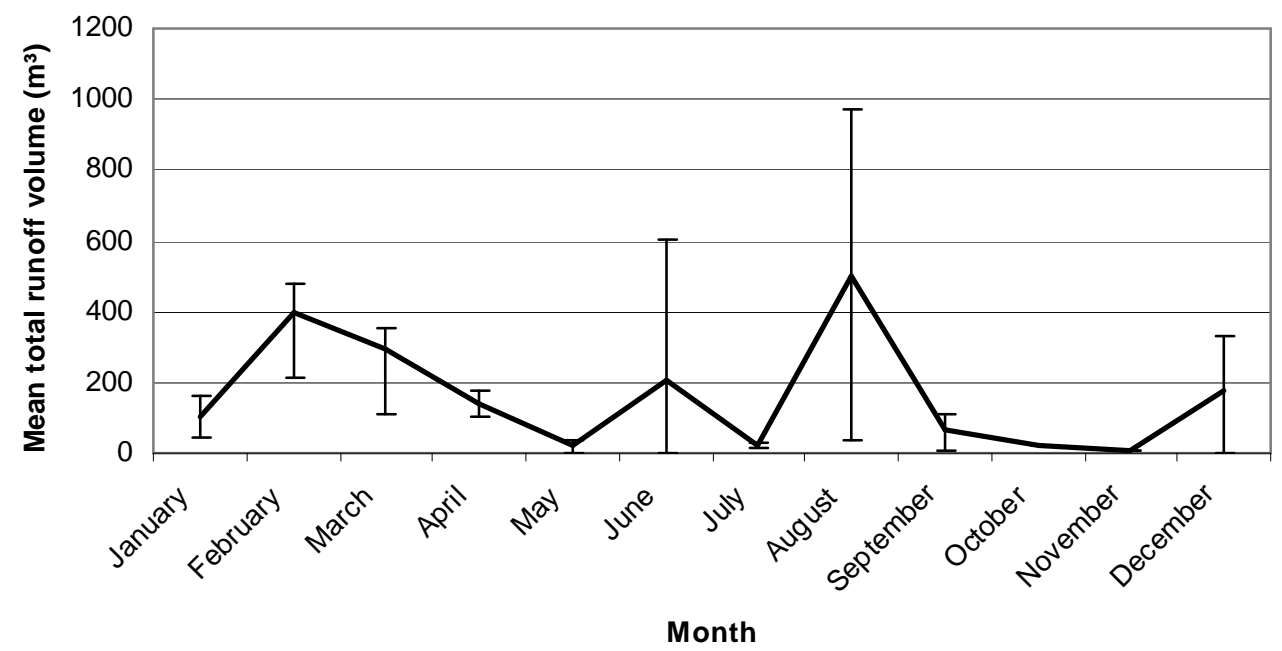

(a)

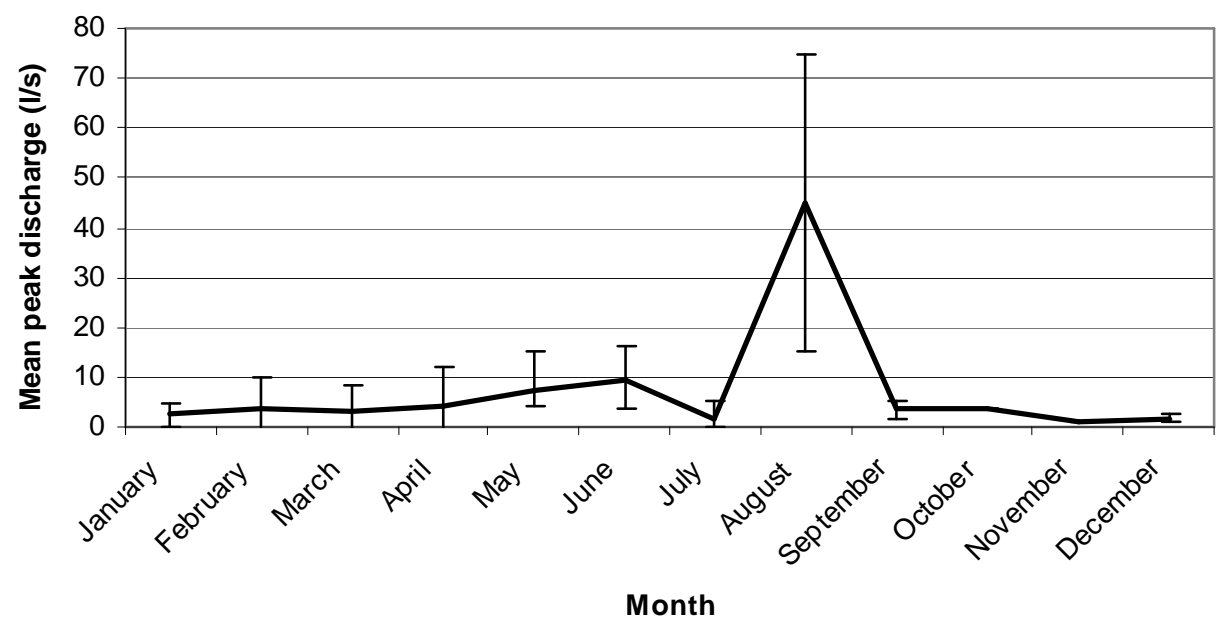

(b)

Figure 10 